\title{
Widespread occurrence of the amphibian chytrid fungus Batrachochytrium dendrobatidis in the southeastern USA
}

\author{
Betsie B. Rothermel ${ }^{1,10, *}$, Susan C. Walls ${ }^{2,11}$, Joseph C. Mitchell ${ }^{3,12}$, \\ C. Kenneth Dodd Jr. ${ }^{4}$, Lisa K. Irwin ${ }^{5,13}$, David E. Green ${ }^{6}$, Victoria M. Vazquez ${ }^{7}$, \\ James W. Petranka ${ }^{8}$, Dirk J. Stevenson ${ }^{9}$
}

${ }^{1}$ Austin Peay State University, The Center of Excellence for Field Biology, PO Box 4718, Clarksville, Tennessee 37044, USA

${ }^{2}$ US Geological Survey, National Wetlands Research Center, 700 Cajundome Blvd., Lafayette, Louisiana 70506, USA

${ }^{3}$ University of Richmond, Department of Biology, Richmond, Virginia 23173, USA

${ }^{4}$ University of Florida, Department of Wildlife Ecology and Conservation, Gainesville, Florida 32611, USA

${ }^{5}$ US Fish and Wildlife Service, Ecological Services, 105 Amity Road, Conway, Arkansas 72032, USA

${ }^{6}$ US Geological Survey, National Wildlife Health Center, 6006 Schroeder Road, Madison, Wisconsin 53711, USA

${ }^{7}$ University of Georgia, Department of Plant Biology, Athens, Georgia 30602, USA

${ }^{8}$ University of North Carolina at Asheville, Department of Biology, Asheville, North Carolina 28804, USA

${ }^{9}$ US Department of Defense, Fort Stewart Fish and Wildlife Branch, 1557 Frank Cochran Drive, Building 1145 , Fort Stewart, Georgia 31314, USA

${ }^{10}$ Present address: Archbold Biological Station, PO Box 2057, Lake Placid, Florida 33862, USA

${ }^{11}$ Present address: US Geological Survey, Florida Integrated Science Center, 7920 NW 71st Street, Gainesville, Florida 32653, USA

${ }^{12}$ Present address: Mitchell Ecological Research Service LLC, PO Box 5638, Gainesville, Florida 32627, USA

${ }^{13}$ Present address: Ouachita Technical College, Arts, Sciences and Education Division, One College Circle, Malvern, Arkansas 72104, USA

\begin{abstract}
From 1999 to 2006, we sampled >1200 amphibians for the fungal pathogen Batrachochytrium dendrobatidis $(B d)$ at 30 sites in the southeastern USA. Using histological techniques or PCR assays, we detected chytrid infection in 10 species of aquatic-breeding amphibians in 6 states. The prevalence of chytrid infection was $17.8 \%$ for samples of postmetamorphic amphibians examined using skin swab-PCR assays ( $\mathrm{n}=202$ samples from 12 species at 4 sites). In this subset of samples, anurans had a much higher prevalence of infection than caudates $(39.2 \%$ vs. $5.5 \%$, respectively). Mean prevalence in ranid frogs was $40.7 \%$. The only infected salamanders were Notophthalmus viridescens at 3 sites. We found infected amphibians from late winter through late spring and in 1 autumn sample. Although we encountered moribund or dead amphibians at 9 sites, most mortality events were not attributed to $B d$. Chytridiomycosis was established as the probable cause of illness or death in fewer than 10 individuals. Our observations suggest a pattern of widespread and subclinical infections. However, because most of the sites in our study were visited only once, we cannot dismiss the possibility that chytridiomycosis is adversely affecting some populations. Furthermore, although there is no evidence of chytrid-associated declines in our region, the presence of this pathogen is cause for concern given global climate change and other stressors. Although presenceabsence surveys may still be needed for some taxa, such as bufonids, we recommend that future researchers focus on potential population-level effects at sites where $B d$ is now known to occur.
\end{abstract}

KEY WORDS: Chytridiomycosis $\cdot$ Batrachochytrium dendrobatidis $\cdot$ Geographic distribution $\cdot$ Acris . Notophthalmus $\cdot$ Pseudacris $\cdot$ Rana 


\section{INTRODUCTION}

A recently identified chytridiomycete fungus (Batrachochytrium dendrobatidis; hereafter $B d$ ) has been implicated as a primary or suspected cause of disease epidemics and subsequent population declines of amphibians in many parts of the world, including Australia, Central America, Europe, Africa, and the western USA (Berger et al. 1998, Daszak et al. 2003, Hopkins \& Channing 2003, Lips et al. 2006). This unusual organism is the only member of the phylum Chytridiomycota known to parasitize vertebrates (Berger et al. 1998, Longcore et al. 1999). Mortality may result from interference with water and ion exchange through the skin (Voyles et al. 2007), but the exact mechanism of pathogenesis is still unclear (Carey et al. 2006). The origin of this pathogen is unknown, although molecular genetic and epidemiological evidence suggests a recent, sudden range expansion, perhaps facilitated by human transport or introduction of a carrier organism (Morehouse et al. 2003, Daszak et al. 2003, Weldon et al. 2004, Morgan et al. 2007).

Recent surveys have confirmed the occurrence of $B d$ in multiple amphibian species in the Pacific Northwest, USA (Pearl et al. 2007), the northeastern USA (Longcore et al. 2007), and eastern Canada (Ouellet et al. 2005). In the southeastern USA, $B d$ infection has been documented in at least 5 species of amphibians, including the American bullfrog Rana catesbeiana (Carey et al. 2003, Green \& Converse 2005, Green \& Dodd 2007, National Wildlife Health Center 1999-2006, available at: www.nwhc.usgs.gov/ publications/quarterly_reports/index.jsp). Bullfrogs seem to be resistant to the disease and could act as reservoir hosts (Daszak et al. 2004). Infection of frog specimens collected at the Savannah River Site (SRS) in South Carolina, USA between 1978 and 1981 implies that this pathogen has been present in the southeastern USA for at least 3 decades (Daszak et al. 2005). An analysis of museum specimens by Ouellet et al. (2005) also confirmed historical infection in green frogs Rana clamitans collected from a site in Virginia, USA in 1980 (M. Ouellet pers. comm.). Bd is still present at SRS (Peterson et al. 2007), although no population declines attributable to chytridiomycosis have been observed at this site or elsewhere in the region (Daszak et al. 2005).

Obtaining information about the geographic distribution and prevalence of $B d$ is an important first step in assessing the threat that this pathogen may pose to the diverse amphibian assemblages in eastern North America. Here we present the results of recent, independent surveys for $B d$ in 9 states in the southeastern USA.

\section{MATERIALS AND METHODS}

We sampled amphibian populations in diverse, relatively protected habitats throughout the southeastern USA between 1999 and 2006. Most of the 30 sites were on lands owned and managed by state or federal natural resource agencies (Appendix 1). Ranid frogs made up a large proportion of samples because these frogs are geographically widespread and relatively abundant. Furthermore, $B d$ has caused disease outbreaks in and population declines of some ranids in western North America (e.g. Rachowicz et al. 2006). We also sampled other amphibian genera opportunistically to obtain information about the taxonomic breadth of host species. Because these surveys were conducted independently by the authors and not as part of a coordinated effort, sampling methods differed across the study.

Sampling of caudates and postmetamorphic anurans. At Chattahoochee River National Recreation Area, Congaree National Park, and Upper Tallulah River, we used dipnetting and hand capture to collect juvenile and adult frogs at night. Each frog was held overnight in an individual plastic container with a small amount of water from the collection site, processed the following morning, and then released near the point of capture within $36 \mathrm{~h}$. To capture plethodontid salamanders, we conducted visual searches of forest floor, stream, and rock face habitats, typically at night. The salamanders collected in Nantahala National Forest were retained for use in another study. We followed the protocols of Livo (2004), swabbing the ventral skin of each adult amphibian (including the hind-toe webbing of anurans) 15 to 20 times and preserving the swabs in vials containing $70 \%$ ethanol. Steps taken to prevent cross-contamination included keeping individuals separate from the time of collection, using a new pair of gloves to handle each animal, and swabbing animals before taking measurements.

At Upham Brook, Camp Lejeune, Fort Stewart, Atchafalaya and Lake Ophelia National Wildlife Refuges, and Sherburne Wildlife Management Area (WMA), juvenile and adult amphibians were collected by dipnet or by hand, kept cool in ice chests, and shipped the following day to the US Geological Survey National Wildlife Health Center (NWHC) in Madison, Wisconsin. The samples from Bald Knob and Big Branch Marsh National Wildlife Refuges (NWR) were collected as part of surveys for amphibian malformations. Only postmetamorphic amphibians with visible limb or other abnormalities were collected, preserved in $75 \%$ ethanol, and shipped to the NWHC for histopathological analysis. In subsequent surveys of NWRs in Arkansas, Louisiana, and Mississippi (Felsenthal, D'Arbonne, Dahomey, and Yazoo), larval anurans were sampled haphazardly and shipped live to the 
NWHC, regardless of whether or not they exhibited abnormalities.

Sampling of larval anurans. We typically collected tadpoles by dipnetting and then preserved them in $10 \%$ formalin, according to the protocol described by McLaughlin et al. (2006). The larvae collected from national fish hatcheries and national wildlife refuges in Arkansas, Louisiana, and Mississippi were sent live to NWHC within 1 to $2 \mathrm{~d}$ of collection. Dead specimens were preserved in either $10 \%$ formalin or $70 \%$ ethanol.

Diagnostic techniques. For anuran larvae $>3 \mathrm{~g}$ body weight, 2 histological sections of each oral disc were stained with hematoxylin and eosin and examined for $B d$ thalli under a binocular light microscope. For larvae $<3 \mathrm{~g}$ body weight, 1 sagittal section of the oral disc and body was examined histologically. For postmetamorphic amphibians, the ventral skin was removed, rolled, and fixed in $10 \%$ formalin and 3 to 6 slices of the skin roll (each 3 to $4 \mathrm{~mm}$ thick) were examined histologically. Skin swabs of salamanders and postmetamorphic frogs were sent to Pisces Molecular Laboratory (Boulder, Colorado, USA) for PCR analysis (Annis et al. 2004). The sensitivity of the PCR assay was at least 0.23 zoospores $\mathrm{ml}^{-1}$ (J. Wood pers. comm.). NWHC routinely performed full necropsies, including histology, on moribund or dead specimens that were not too seriously decomposed.

Estimating prevalence. We restricted estimation of prevalence to a subset of skin swab samples of postmetamorphic amphibians ( $\mathrm{n}=202$ individuals of 12 species) that were tested using PCR. Confidence limits for the binomial parameter (i.e. proportion of individuals that tested positively for $B d$ ) were calculated according to Zar (1999). The skin swab samples were collected as part of pre-planned surveys for $B d$ at Congaree National Park, Nantahala National Forest, Upper Tallulah River, and Chattahoochee River National Recreation Area. Amphibians at these sites were sampled regardless of whether or not there was any evidence to suggest disease agents were present. In contrast, many of the samples sent to NWHC for histopathological examination consisted of only dead, moribund, or malformed amphibians, which would clearly bias estimates of population-level prevalence (McCallum 2005). Furthermore, because disease surveys were often a secondary objective or sampling was opportunistic, collectors often submitted $<10$ individuals of a particular species collected on a given date from the same site. Such small sample sizes could result in sampling biases and erroneous estimates of prevalence. In addition, histology is less sensitive than PCR (Boyle et al. 2004). Therefore, the results from histology are best interpreted as site-level presence or absence of $B d$.

\section{RESULTS}

We found $B d$ infection in 10 species of aquaticbreeding amphibians in 6 of the 9 states we surveyed (Table 1, Fig. 1). No amphibians sampled from sites in Florida, Mississippi, or Tennessee were infected. Because the ability to detect $B d$ depends on sample size and prevalence of infection, we examined the adequacy of our sampling effort at sites where we did not detect $B d$ by calculating approximate confidence levels (DiGiacomo \& Koepsell 1986; Table 2). The mean confidence level (i.e. probability of detecting $B d$ when prevalence was $\leq 1 \%$ ) for the sites where $B d$ was not detected was only $24.6 \%$ (range $1.0-71.2 \%$; Table 2 ), implying that non-detection of $B d$ at these sites should not be interpreted as absence of $B d$.

Of the 202 skin swab samples of postmetamorphic amphibians, 36 tested positively for Bd (Table 3), yielding an overall prevalence estimate of $17.8 \%$. Anurans had a much higher prevalence of infection than caudates (39.2\% vs. $5.5 \%$, respectively). Mean prevalence of infection in postmetamorphic ranids was $40.7 \%$ (range 27.8-61.1\%, Table 3). At least 1 larval or postmetamorphic ranid was infected at 11 of the 25 sites where we sampled ranids (Fig. 2). Several hylids were also infected (Table 1, Fig. 2). The only infected salamanders were broken-striped newts Notophthalmus viridescens dorsalis at Camp Lejeune and red-spotted newts N. v. viridescens at Mountain Lake Biological Station and Upper Tallulah River (Fig. 2).

We found infected amphibians from late winter (6 February) through late spring (20 June) and in 1 autumn sample from the Upper Tallulah River site (10 September, Fig. 3). We did not find infected amphibians in the warmest months of the year (July-August), but our sampling effort was relatively low in those months (Fig. 3). Importantly, we only found 2 dead frogs (1 at Camp Lejeune and 1 at Upper Tallulah River) and 2 dead newts (at Mountain Lake Biological Station) that tested positively for $B d$. Although we observed mortality events involving larger numbers of amphibians at Great Smoky Mountains National Park, Tulula Wetlands Mitigation Site, University of Tennessee Arboretum, St. Marks National Wildlife Refuge, Ordway-Swisher Biological Station, and Withlacoochee State Forest, diagnostic examinations implicated factors other than $B d$. Site-specific findings are described below.

\section{Arkansas}

Bald Knob NWR. Fifty postmetamorphic northern cricket frogs Acris crepitans were collected and inspected for abnormalities. Two adults with limb 
Table 1. Summary of species and number of amphibian individuals infected with Batrachochytrium dendrobatidis $(B d)$. Surveys were conducted in 9 southeastern states (USA) from 1999 to 2006 (AR = Arkansas, FL = Florida, GA = Georgia, LA = Louisiana, MS = Mississippi, $\mathrm{NC}=$ North Carolina, $\mathrm{SC}=$ South Carolina, $\mathrm{TN}=$ Tennessee, $\mathrm{VA}=$ Virginia). In some instances, only a subsample of amphibians submitted to NWHC was examined by histology; exact number of specimens examined is unavailable. For this and other reasons (see 'Materials and methods'), numbers given here should not be used to estimate prevalence. Bold indicates states where $B d$ was detected in a given species

\begin{tabular}{|c|c|c|c|}
\hline Species & $\begin{array}{l}\text { Total no. } \\
\text { collected }\end{array}$ & $\begin{array}{c}\text { No. } \\
\text { infected }\end{array}$ & State \\
\hline \multicolumn{4}{|l|}{ Anurans } \\
\hline Acris crepitans & 5 & 5 & AR, LA \\
\hline Acris gryllus & 25 & 0 & FL \\
\hline Bufo americanus & 1 & 0 & GA \\
\hline Bufo fowleri & 19 & 0 & GA, LA \\
\hline Bufo nebulifer & 10 & 0 & LA \\
\hline Bufo quercicus & 1 & 0 & FL \\
\hline Bufo terrestris & 9 & 0 & $\mathrm{NC}, \mathrm{SC}$ \\
\hline Eleutherodactylus planirostris & 4 & 0 & FL \\
\hline Hyla cinerea & 14 & 0 & GA, FL, NC, SC \\
\hline Hyla femoralis & 10 & 0 & FL, SC \\
\hline Hyla gratiosa & 9 & 0 & FL \\
\hline Hyla squirella & 28 & 0 & FL \\
\hline Hyla versicolor/chrysoscelis & 9 & 1 & LA \\
\hline Osteopilus septentrionalis & 5 & 0 & FL \\
\hline Pseudacris crucifer & 39 & 5 & LA, GA, TN \\
\hline Pseudacris feriarum & 4 & 0 & $\mathrm{TN}$ \\
\hline Pseudacris fouquettei & 34 & 4 & LA \\
\hline Pseudacris sp. & 1 & 0 & $\mathrm{TN}$ \\
\hline Rana capito & 18 & 0 & GA, FL \\
\hline Rana catesbeiana & 229 & 5 & $\begin{array}{l}\text { GA, NC, VA, FL, LA, } \\
\text { MS, SC }\end{array}$ \\
\hline Rana clamitans & 76 & 5 & GA, LA, FL, SC \\
\hline Rana grylio & 18 & 0 & FL \\
\hline Rana palustris & 35 & 23 & GA, SC, TN \\
\hline Rana sphenocephala & 301 & 12 & $\begin{array}{l}\text { AR, LA, NC, FL, GA, } \\
\text { MS, SC }\end{array}$ \\
\hline Rana sylvatica & 80 & 1 & GA, TN \\
\hline Rana sp. & 7 & 3 & GA \\
\hline \multicolumn{4}{|l|}{ Caudates } \\
\hline Ambystoma maculatum & 43 & 0 & $\mathrm{TN}$ \\
\hline Ambystoma opacum & 3 & 0 & TN \\
\hline Ambystoma talpoideum & 1 & 0 & MS \\
\hline Ambystoma tigrinum & 2 & 0 & GA \\
\hline Desmognathus monticola & 63 & 0 & GA, NC \\
\hline Desmognathus quadramaculatus & 1 & 0 & GA \\
\hline Gyrinophilus porphyriticus & 1 & 0 & TN \\
\hline Notophthalmus viridescens & 63 & 16 & GA, NC, VA, LA, TN \\
\hline Plethodon metcalfi & 54 & 00 & $\mathrm{NC}$ \\
\hline Plethodon serratus & 1 & 0 & $\mathrm{NC}$ \\
\hline
\end{tabular}

Felsenthal NWR. Twelve larval southern leopard frogs Rana sphenocephala were collected and submitted live to NWHC for histological examination. Seven of these tadpoles were infected with $B d$. These animals were collected from contaminated pools in an oil production site on the refuge.

\section{Florida}

Ordway-Swisher Biological Station. Approximately 30 dead anurans were found during a substantial morbidity and mortality event in March 2005 at

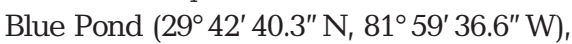
an isolated, semi-permanent clear water lake. Larval Rana sphenocephala specimens $(\mathrm{n}=17)$ were collected and submitted to NWHC for necropsies and histological examination. The mortality was attributed to a virulent unnamed, unicellular microorganism, possibly related to alveolate organisms or the genus Perkinsus, which has affected other spring-breeding ranids (Davis et al. 2007, NWHC 2005). At present, the organism has not been cultured and is diagnosed histologically based on massive numbers of the microscopic spherical organisms in most major visceral organs. Samples were negative for $B d$.

St. Marks NWR. Larval anurans of 7 species ( $\mathrm{n}=138$ ) and 1 postmetamorphic oak toad Bufo quercicus were examined from 9 wetland sites within this coastal refuge in 2002, 2003, and 2005. Various ecto- and endoparasites were found. The virulent Perkinsuslike organism was found only at Perkinsus Pond, $\left(30^{\circ} 3^{\prime} 38.6^{\prime \prime} \mathrm{N}, 84^{\circ} 23^{\prime}\right.$ $\left.45.8^{\prime \prime} \mathrm{W}\right)$, where significant morbidity and mortality occurred in December 2002, February 2003, and May 2003;

abnormalities were preserved and submitted to NWHC for radiographic and histological examination; both were subsequently diagnosed with chytridiomycosis (D. E. Green pers. obs.). These animals were collected from shallow pools and tire ruts in a fallow rice field. Hundreds of tadpoles (Rana spp., Bufo spp., and Hyla spp.) were monitored during 4 additional visits to the site, but no samples were collected because the pools dried prior to metamorphosis. larval southern cricket frogs (Acris gryllus) and $R$. sphenocephala were infected. $B d$ was not found in any specimens examined by NWHC.

Withlacoochee State Forest. A significant morbidity and mortality event occurred in 2 ponds (Croom 15 and 16 ; $28^{\circ} 35^{\prime} 52.9^{\prime \prime} \mathrm{N}, 82^{\circ} 14^{\prime} 59.4^{\prime \prime} \mathrm{W}$ and $28^{\circ} 35^{\prime} 51.1^{\prime \prime} \mathrm{N}$, $82^{\circ} 14^{\prime}$ 56.4" W, respectively) at this site in March 2005. Hundreds of dead and dying tadpoles of gopher frog Rana capito, $R$. catesbeiana, and $R$. sphenocephala were 


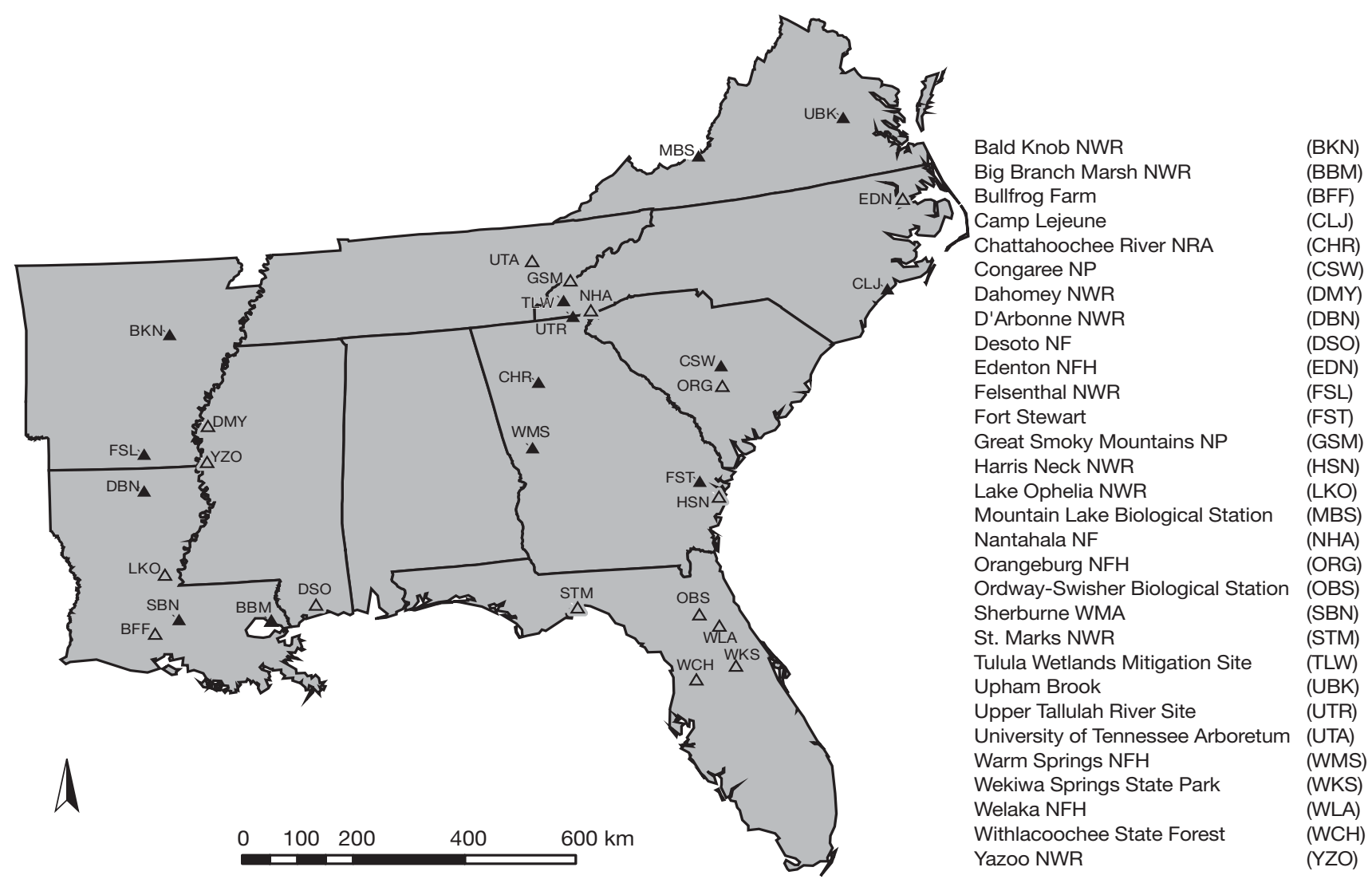

Fig. 1. Locations of 30 sites in the southeastern USA where amphibians were collected and tested for Batrachochytrium dendrobatidis infection. $\Delta$ : sites where no infection was detected; $\mathbf{\Delta}$ : sites where at least 1 individual was found to be infected. On average, 3 species and 41 individual amphibians were collected per site (range 1-9 and 2-143, respectively). See Appendix 1 for site details

found in the shallow, clear waters of these ponds. No $B d$ was found in histological examinations of approximately 40 larvae. Instead, histological examination revealed that larvae were infected with the unnamed Perkinsuslike (or alveolate) micro-organism (Davis et al. 2007, NWHC 2005).

Wekiwa Springs State Park. Frogs were collected in December 2004 from ground litter and adjacent vegetation along a minor spring run. Four adult terrestrial greenhouse frogs Eleutherodactylus planirostris and 5 arboreal Cuban treefrogs Osteopilus septentrionalis were collected from mesic forest in the park. A number of endoparasites were found, but there was no evidence of $B d$ infection.

\section{Georgia}

Chattahoochee River National Recreation Area. We captured and sampled 19 postmetamorphic frogs and 39 ranid larvae during 3 visits in the spring of 2005, mainly from ponds and beaver wetlands in the Johnson Ferry Unit. Histological examination revealed $B d$ infection in 2 larval Rana clamitans. Of 18 postmetamorphic ranids 5 were also infected according to PCR (Table 3), but no clinical signs of disease were observed.

Fort Stewart. No $B d$ infection was detected in larval or adult Rana capito, in larval or juvenile $R$. sphenocephala, nor in postmetamorphic $R$. catesbeiana, central newts Notophthalmus viridescens. louisianensis, and eastern tiger salamanders Ambystoma tigrinum tigrinum. However, 12 of $56 R$. catesbeiana tadpoles were infected with $B d$. All of these individuals were collected in March 2002 from a deep, vegetation-lined ditch in mesic pine flatwoods.

Harris Neck NWR. Ten larval Rana catesbeiana from 2 adjacent ponds were collected in July 2005. Both endo- and ectoparasites were identified, but no evidence of $B d$ infection was found.

Upper Tallulah River. We found no $B d$ infection in 4 postmetamorphic ranids and 10 stream salamanders Desmognathus spp. sampled in September 2005, nor in 12 adult spring peepers Pseudacris crucifer sampled in April 2006. However, 3 of 7 larval ranids (Rana catesbeiana or R. clamitans) collected in September 2005, and 7 of 10 adult Notophthalmus viridescens viri- 
Table 2. Approximate confidence levels for sites where we did not detect Batrachochytrium dendrobatidis (site abbreviations as in Fig. 1; some sites were sampled in multiple years). Confidence estimates assume that individuals collected were a random sample and that diagnostic sensitivity was $100 \%$, assumptions which were rarely met (see 'Materials and methods'). Samples from NHA were analyzed with PCR; the rest were analyzed by histology. See Table 1 legend for state abbreviations

\begin{tabular}{|ccccc|}
\hline State & Site & Sampling date & $\mathrm{n}$ & $\begin{array}{c}\text { Confidence } \\
\text { level (\%) when } \\
\text { prevalence }=1 \%\end{array}$ \\
\hline FL & & & & OBS \\
& STM & Dec 2002-Aug 2003 & 124 & 71.2 \\
& STM & Jun 2005 & 15 & 14.0 \\
& WKS & Dec 2004 & 9 & 8.6 \\
& WLA & Jun 2005 & 78 & 54.3 \\
& WCH & Mar 2005 & 40 & 33.1 \\
GA & HSN & Jul 2004 & 10 & 9.6 \\
LA & BFF & Apr 2002 & 12 & 11.4 \\
& LKO & May 2002 & 11 & 10.5 \\
MS & DMY & May 2005 & 26 & 23.0 \\
& DSO & Mar 2001 & 9 & 8.6 \\
& DSO & May 2003-Feb 2004 & 26 & 23.0 \\
& YZO & Jun 2005 & 10 & 9.6 \\
NC & EDN & Jun 2005 & 17 & 15.7 \\
& GSM & Jun 1999-May 2000 & 29 & 25.3 \\
& GSM & Feb 2001-May 2001 & 113 & 67.9 \\
& GSM & May 2003 & 1 & 1.0 \\
& NHA & Apr 2006 & 108 & 66.2 \\
SC & ORG & Jun 2005 & 16 & 14.9 \\
TN & UTA & Mar 2004 & 8 & 7.7 \\
& & & & \\
\hline
\end{tabular}

Table 3. Observed prevalence of Batrachochytrium dendrobatidis infection (95\% confidence limits) in postmetamorphic amphibians tested using skin swab-PCR assays. Prevalence estimates are given for sites having at least 1 positive detection and a sample size of at least 5 individuals per genus. Site abbreviations as in Fig. 1

\begin{tabular}{|c|c|c|c|c|}
\hline Site & Species & $\begin{array}{l}\text { No. } \\
\text { tested }\end{array}$ & $\begin{array}{c}\text { No. } \\
\text { infected }\end{array}$ & $\begin{array}{c}\text { Prevalence } \\
(\%)\end{array}$ \\
\hline CHR & $\begin{array}{l}\text { Rana catesbeiana, } R \text {. clamitans, } \\
\text { R. sphenocephala }\end{array}$ & 18 & 5 & $27.8(9.7,53.5)$ \\
\hline CHR & Bufo americanus & 1 & 0 & - \\
\hline CSW & $\begin{array}{l}\text { R. catesbeiana, } R . \text { clamitans, } \\
\text { R. palustris, } R . \text { sphenocephala }\end{array}$ & 36 & 22 & $61.1(43.5,76.9)$ \\
\hline CSW & B. terrestris & 1 & 0 & - \\
\hline NHA & Desmognathus monticola & 54 & 0 & - \\
\hline NHA & Plethodon metcalfi & 54 & 0 & - \\
\hline UTR & $\begin{array}{l}R . \text { catesbeiana, } R \text {. clamitans, } \\
R . \text { palustris, } R \text {. sylvatica }\end{array}$ & 6 & 2 & $33.3(4.3,77.7)$ \\
\hline UTR & Pseudacris crucifer & 12 & 0 & - \\
\hline UTR & $\begin{array}{l}\text { Notophthalmus viridescens } \\
\text { viridescens }\end{array}$ & 10 & 7 & $70.0(34.7,93.3)$ \\
\hline UTR & D. monticola, D. quadramaculatus & 10 & 0 & - \\
\hline \multicolumn{2}{|c|}{ Total (all species and sites) } & 202 & 36 & 17.8 \\
\hline
\end{tabular}

descens sampled in April 2006 were infected. In addition, 1 adult pickerel frog $R$. palustris and 1 adult wood frog $R$. sylvatica sampled in April 2006 tested positively for $B d$ (Table 3$)$. The single $R$. sylvatica was a dead, partially decomposed individual found at the edge of a pool in a meadow. Two of the larval $R$. catesbeiana had deformities of the tail or mouthparts. All other specimens appeared healthy.

\section{Louisiana}

Big Branch Marsh NWR. During May 2002, 3 cohorts of recently metamorphosed Rana clamitans (total $\mathrm{n}=$ 110) were collected from a wetland area bounded by residential development. Two individuals with limb abnormalities were preserved and submitted to NWHC for radiographic and histological examination. Both specimens were infected with $B d$.

D'Arbonne NWR. During April and May 2005, tadpoles were collected from 3 sites in D'Arbonne NWR. A total of 35 larval anurans from 2 species was collected and submitted live to NWHC. Although no $B d$ was detected in 22 Cajun chorus frogs Pseudacris fouquettei collected in flooded backwater areas, 2 of 13 larval Rana sphenocephala collected from a roadside ditch were infected.

Sherburne WMA, Atchafalaya NWR, and Lake Ophelia NWR. From April to June 2002, postmetamorphic and larval anurans were captured and sampled from 7 sites within these areas. Individuals were also collected from a privately-owned Rana catesbeiana farm in Lafayette Parish. A total of 26 postmetamorphic anurans and 72 larvae from 8 species were collected and examined. Three adult Acris crepitans died shortly after arrival at $\mathrm{NWHC}$; the skins of all 3 were heavily infected with $B d$, suggesting chytridiomycosis was the cause of death (D. E. Green pers. obs.). Histological examination also revealed $B d$ infection in 2 of 11 Pseudacris crucifer tadpoles, and in 3 of $10 \mathrm{P}$. fouquettei tadpoles. All of the infected individuals collected in 2002 were from Sherburne WMA. $B d$ was also found in 1 of 9 adult Cope's gray treefrogs Hyla chrysoscelis, 3 of 9 adult $P$. crucifer and 1 of 2 adult $P$. fouquettei collected in Sherburne WMA in February 2005. Although $B d$ infections have been reported previously in adult $A$. crepitans and adult western chorus frogs P. triseriata (Carey et al. 2003, 

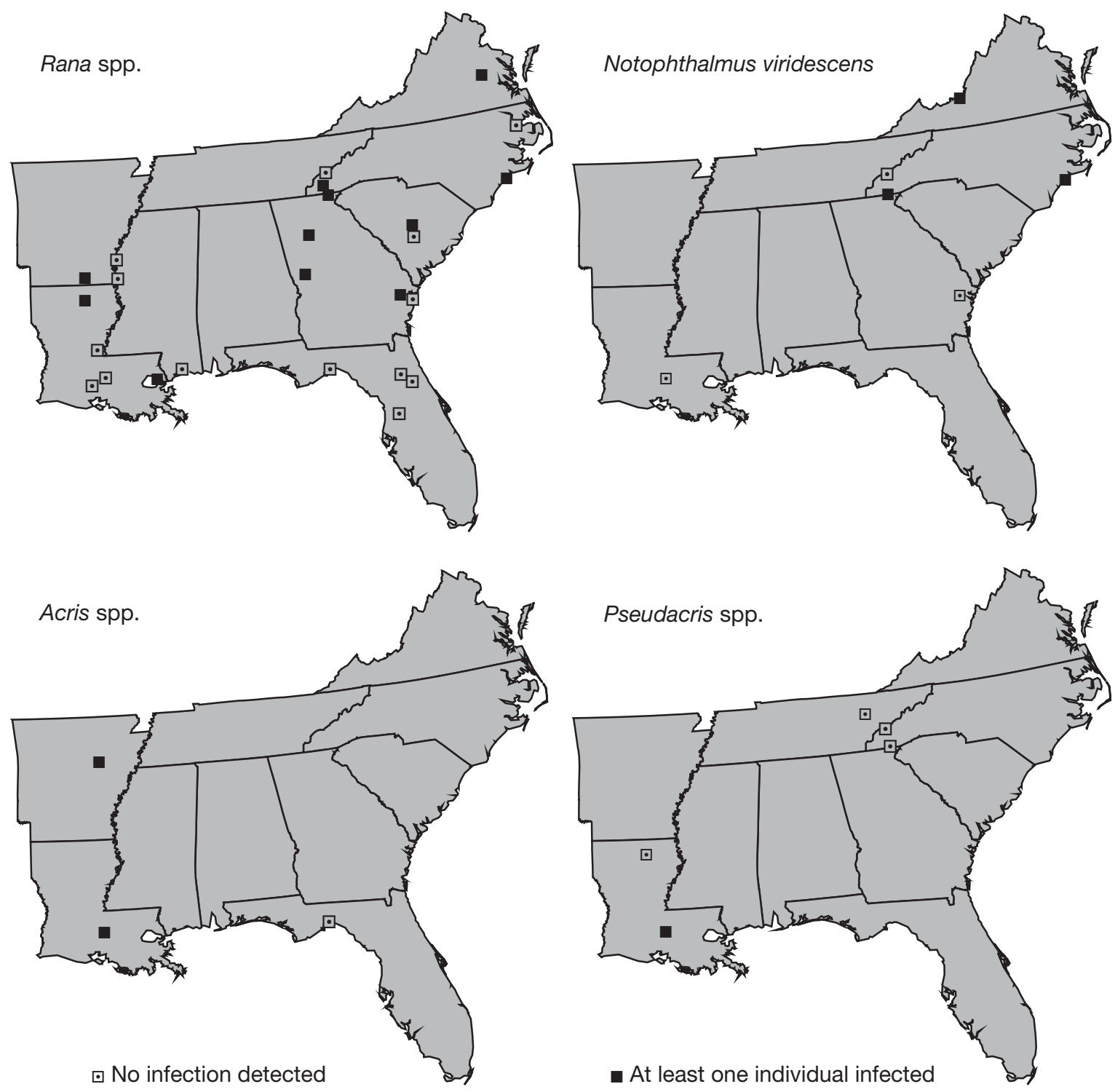

Fig. 2. Geographic distribution of Batrachochytrium dendrobatidis infection in 4 amphibian taxa that were sampled at multiple sites in the southeastern USA. Infection was also detected in 1 of 9 gray treefrogs (Hyla versicolor or H. chrysoscelis) at Sherburne Wildlife Management Area in Louisiana, the only site where this species was collected

Ouellet et al. 2005), this is the first report of infection in $P$. crucifer and P. fouquettei.

\section{Mississippi}

Dahomey NWR. Twenty-six larval Rana sphenocephala were collected from a man-made ditch and a cultivated field in May 2005. None of the larvae submitted live to NWHC was infected with $B d$.

Desoto National Forest. In March 2001 and May 2003, 25 larval and adult Rana sphenocephala and 1 larval Ambystoma talpoideum specimens were collected from Pony Ranch Pond, Reserve Pond, and
Glen's Pond. In February 2004, 9 tadpoles of $R$. sphenocephala were also collected from the Rifle Range borrow pit in Harrison County, MS. None of these specimens was infected with $B d$.

Yazoo NWR. Ten larval Rana catesbeiana were collected from a man-made pond in June 2005 and were submitted live to NWHC; $B d$ was not detected in any of the larvae.

\section{North Carolina}

Camp Lejeune. We sampled 2 anuran species (Rana catesbeiana and R. sphenocephala) and Notophthal- 

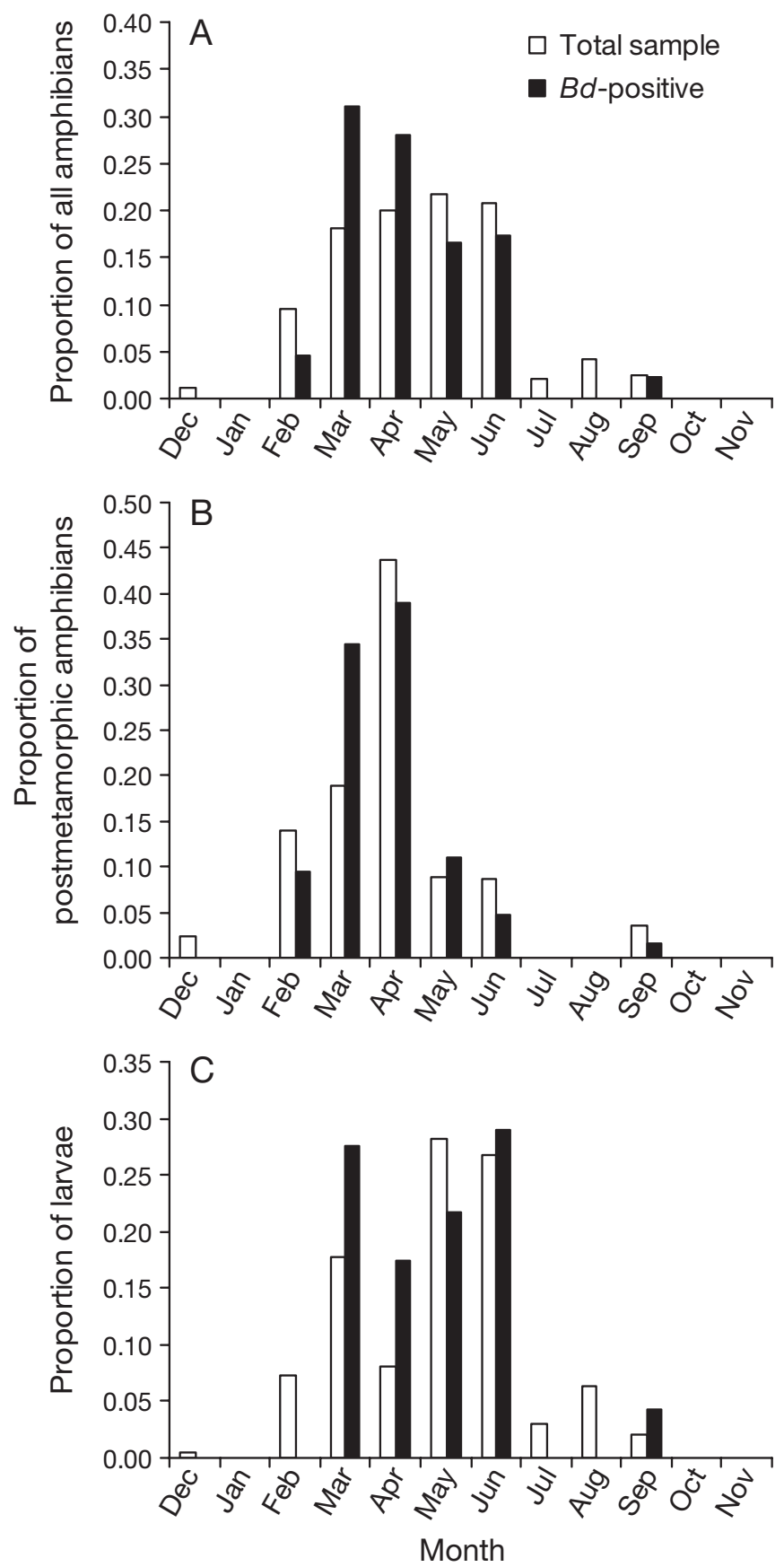

Fig. 3. Monthly distribution of sampling effort. (A) Data pooled across species, life stages, sites $(n=30)$, and years (1999-2006); (B) postmetamorphic amphibians only (includes subadults and adults of direct-developing species); (C) larval amphibians only ( $\leq$ Gosner stage 46 )

mus viridescens dorsalis at Camp Lejeune. Of $33 R$. catesbeiana tadpoles examined, 5 were positive for $B d$. Only 1 of 8 recently metamorphosed $R$. catesbeiana was positive. Both recently metamorphosed R. sphenocephala were positive, as well as 1 adult that was found dead in February 2000 and diagnosed with chytridiomycosis by NWHC (Green et al. 2002). Of 13 N. v. dorsalis collected in 2002, 7 were also infected. All of the amphibians collected at Camp Lejeune were from 3 temporary limesink ponds that are connected during heavy rains via sheet-flow.

Nantahala National Forest. Samples from 54 southern gray-cheeked salamanders Plethodon metcalfi and 54 seal salamanders Desmognathus monticola were negative for $B d$ according to PCR. The specimens were collected from multiple stream and forest sites within a $6 \mathrm{~km}$ radius of the Highlands Biological Station in April 2006.

Tulula Wetlands Mitigation Site. Of 14 overwintering Rana catesbeiana larvae with missing or degraded mouthparts collected in May 2005, 13 were infected with $B d$. Catastrophic die-offs of R. sylvatica and spotted salamander Ambystoma maculatum larvae were documented at this site annually from 1997 to 2006, but were attributed to ranaviral infections (Petranka et al. 2007).

\section{South Carolina: Congaree National Park}

We captured and sampled 37 frogs around Weston Lake and the Sims Trail during 2 visits in March 2005. Of 29 postmetamorphic Rana palustris, 22 tested positively for $B d$. None of the other species tested positively. Although $61.1 \%$ of ranid frogs were infected (Table 3), we observed no clinical signs of disease.

\section{Tennessee}

Great Smoky Mountains National Park. Amphibian morbidity and mortality were recorded annually between 1999 and 2001 at Gourley Pond in Cades Cove; no other sites within the cove or elsewhere throughout the park were observed to have similar mortality events. Iridovirus (Ranavirus) and/or fungi (Ichthyophonus sp.) were found in a number of anuran and salamander species (Dodd 2004). No Bd was found in the specimens submitted to NWHC (Table 2).

University of Tennessee Arboretum. Eight dead, postmetamorphic chorus frogs (Pseudacris spp.) were found next to the Forestry Station garage in March 2004 . None was infected with $B d$. The only pathological findings noted by NWHC were the presence of microscopic breaks in the skin and minute $(<0.2 \mathrm{~mm}$ diameter) shiny, spherical beads of solder-like metal in the epidermis, which implicated chemical contamination from human activities in the garage. Some dead individuals were also found in spring 2006, but the specimens were too desiccated for diagnostic examination. 


\section{Virginia}

Mountain Lake Biological Station. Eight sick or dead Notophthalmus viridescens viridescens individuals were observed in Sylvatica and Horton ponds (both at $37^{\circ} 22^{\prime} 32^{\prime \prime} \mathrm{N}, 80^{\circ} 31^{\prime} 20^{\prime \prime} \mathrm{W}$ ) between 22 April and 14 May 2006 (K. Grayson pers. comm.). Two of the redspotted newts were collected and submitted to NWHC for histopathological examination and both were found to have mild $B d$ infections. Chytridiomycosis was the most likely cause of death because no viruses or other diseases were detected. However, these infected individuals were not part of a mass mortality event; researchers conducting mark-recapture studies of $N$. $v$. viridescens annually since 2006 have found no additional newts or other amphibians exhibiting symptoms of chytridiomycosis, nor have they observed population declines in these ponds (K. Grayson pers. comm.).

Upham Brook, Virginia. Of 17 Rana catesbeiana tadpoles and $3 R$. catesbeiana metamorphs, 16 and 2 (respectively) were infected with $B d$. The infected specimens were obtained near the headwaters and in a tributary that drains a residential area and railroad yard.

\section{National Fish Hatcheries (NFH)}

$B d$ was detected histologically in 4 of 5 larval Rana catesbeiana specimens collected in June 2005 at Warm Springs NFH in Georgia. Bd was not detected in 4 larval Fowler's toads Bufo fowleri, 5 larval green treefrogs Hyla cinerea, and 4 larval $R$. clamitans collected from the same ponds and examined by histology. A total of 111 larvae of 7 species from Orangeburg NFH in South Carolina, Edenton NFH in North Carolina, and Welaka $\mathrm{NFH}$ in Florida was also examined, but none was infected with $B d$ (see Green \& Dodd 2007 for details).

\section{DISCUSSION}

Ecological niche modeling conducted by Ron (2005) suggests that the entire eastern USA has environmental conditions suitable for $B d$. Our surveys confirmed the presence of $B d$ in geographically disparate populations of 10 species of amphibians in 6 states, implying that this pathogen is widespread in the southeastern USA. This finding is consistent with those of Ouellet et al. (2005) and Green \& Converse (2005), i.e. that Bd is common and enzootic in eastern North America. The prevalence we observed in postmetamorphic amphibians in the southeastern USA $(17.8 \%$; Table 3$)$ was the same as that observed in postmetamorphic amphibians in Quebec, Canada in 1990-2001 (Ouellet et al. 2005).
However, we found $B d$ infection in anurans to be more widespread in southeastern USA (39.2\%) than in northeastern USA (19.8\%; Longcore et al. 2007). Some of this difference could be attributed to our use of more sensitive genetic assays, instead of histology, to detect $B d$. Although we did not find $B d$ in samples from Florida, Mississippi or Tennessee, this was probably because of inadequate sampling rather than absence of $B d$ (Table 3).

\section{$B d$-associated mortality}

Despite the ubiquity of $B d$, we found few clinical signs of disease in infected, wild-caught amphibians. The only sick or dead amphibians diagnosed with chytridiomycosis in our study were 2 adult Acris crepitans from Bald Knob NWR, 3 adult A. crepitans from Sherburne WMA, 1 adult Rana sphenocephala at Camp Lejeune, and 2 adult Notophthalmus viridescens viridescens from Mountain Lake Biological Station. Although the 1 dead R. sylvatica at the Upper Tallulah River site tested positively for $B d$, it was too decomposed to determine cause of death. No additional mortality was observed in subsequent visits to Camp Lejeune, Upper Tallulah River, or Mountain Lake (J. C. Mitchell \& B. B. Rothermel pers. obs., K. Grayson pers. comm.). The cause of death of specimens collected during mortality events at other sites was attributed to agents other than $B d$, such as Ranavirus or the Perkinsus-like organism, a trend consistent with previously recorded mortality events in the region (Green et al. 2002).

\section{Host species}

The taxonomic breadth of species known to be infected with $B d$ in this region is greater than previously documented. Green \& Converse (2005) reported chytridiomycosis in 20 species of adult frogs from 15 states, including 5 species in the southeastern USA. As in other studies (e.g. Longcore et al. 2007, Pearl et al. 2007), we found a high prevalence of $B d$ infection in ranid frogs (Table 3). Because ranids have relatively long larval periods and inhabit more permanent wetlands, they may have a greater risk of exposure to $B d$ than species with short larval periods that breed in small, ephemeral bodies of water. Whereas Kriger \& Hero (2007) observed high prevalence of infection in frogs breeding in permanent waterbodies, they did not detect $B d$ in frogs breeding in ephemeral waterbodies. This was expected, given the susceptibility of $B d$ to desiccation, lack of a resting stage, and reliance on flagellated zoospores for dispersal (Longcore et al. 1999). 
In contrast to studies in other regions of North America, we documented infection in several species of hylids, especially at the Sherburne WMA in southwestern Louisiana. The finding of infected Pseudacris crucifer and $P$. fouquettei at Sherburne WMA is the first report of $B d$ in these species. Interestingly, none of the 44 individual ranids collected from Sherburne WMA or a nearby Rana catesbeiana farm was infected.

We found no $B d$ infection in bufonids. However, we tested only 40 individuals from 7 sites. Histological examination of 12 American toad Bufo americanus specimens collected in Virginia in 1980 also yielded negative results (M. Ouellet pers. comm.). In contrast, Longcore et al. (2007) found that $15 \%$ of B. americanus in Maine were infected, and noted that bufonids generally had heavy infections. The limited sampling in the southeastern USA and use of different diagnostic techniques in each of these studies precludes regional comparisons. The sparse data on toads in the eastern USA is unfortunate because bufonids have been one of the taxa most affected by chytridiomycosis in the western USA and in Central America (Green et al. 2002, Pounds et al. 2006). Future sampling efforts should concentrate on bufonids to obtain information about $B d$ in these species.

Our finding of infected eastern newts Notophthalmus viridescens in 3 states suggests $B d$ infection may be widespread in this species. Ouellet et al. (2005) also documented infection in newt specimens from sites in Canada. Padgett-Flohr et al. (2007) detected Bd in commercially purchased newts, but did not provide information on the ultimate source of these animals. We did not detect $B d$ in 5 species of plethodontid or 4 species of ambystomatid salamanders.

\section{Seasonal occurrence of $\boldsymbol{B d}$}

We found infected larvae and postmetamorphic individuals primarily from February to June. We also collected infected ranid larvae in September. Previous studies document seasonal variation in $B d$ prevalence in anurans. Retallick et al. (2004) found higher levels of infection in winter and spring than in summer and autumn at rainforest sites in Australia. Similarly, Kriger \& Hero (2006) found that $B d$ prevalence in eastern Australia peaked in early spring and declined precipitously in late summer when mean (30 d) air temperatures exceeded $19.4^{\circ} \mathrm{C}$. Our data for the southeastern USA suggest that the higher prevalence in spring (March and April) is not simply an artifact of greater sampling effort in these months (Fig. 3). Likewise, $B d$ prevalence in Quebec was higher in spring but there was also an increased prevalence in fall (Ouellet et al. 2005), a pattern we could not assess because we did not collect any samples in October or November.

\section{Implications and recommendations}

Given the long history of herpetological studies in the southeastern USA, we believe that catastrophic die-offs of amphibians during the last half-century would have been noted and we know of no such records. At present, the best available evidence suggests that amphibian populations in the southeastern USA are not severely affected, exhibiting primarily subclinical infections. This is in stark contrast to the pattern of chytrid-associated declines and extinctions in Central and South America (Lips et al. 2008) and the Sierra Nevada of California (Rachowicz et al. 2006). If $B d$ is not endemic to the southeastern USA, then the strain introduced there (some time prior to 1978) may be less virulent than the strains causing epidemics elsewhere (Berger et al. 2005, Daszak et al. 2005, Retallick \& Miera 2007). Alternatively, Bd may have existed in the southeastern USA for sufficient time to allow the evolution of resistance to disease or of less-pathogenic genotypes (Retallick et al. 2004, Morgan et al. 2007).

Another possibility is that host-pathogen interactions and environmental factors in the southeastern USA may be unfavorable for the development of clinical disease due to $B d$. For example, on the Coastal Plain, temperatures may be too high during much of the year, therefore limiting the growth and spread of $B d$ (Daszak et al. 2005). The question remains as to why we have not seen epidemics at cooler, higher elevations in the Piedmont and Blue Ridge physiographic regions, places where we have now documented $B d$ occurrence. Temperature increases due to climate warming have been proposed as contributing factors in outbreaks of chytridiomycosis in montane regions of Costa Rica (Pounds et al. 2006, but see Lips et al. 2008) and Spain (Bosch et al. 2007). However, we do not think that minimum temperatures constrain $B d$ growth in the southeastern USA, because die-offs attributed to chytridiomycosis have occurred in much colder montane sites, such as the Rocky Mountains (Muths et al. 2003) and Sierra Nevadas (Briggs et al. 2005). A useful avenue for future research would be to conduct predictive modeling to identify areas in the southeastern USA that have present (or future) climatic regimes most favorable to $B d$.

We cannot dismiss the possibility that some amphibian populations in the southeastern USA are being negatively affected by chytridiomycosis. At the local (pond) level, sporadic die-offs could have occurred that were not detected by herpetologists. Fewer than half of the sites in our study were visited on more than 1 occasion, and amphibian carcasses would be expected to decompose rapidly in our climate. Green et al. (2002) cautioned that $B d$ epizootics are insidious and persis- 
tent. Although researchers in Panama (Lips et al. 2006) and California (Rachowicz et al. 2006) frequently found deceased postmetamorphic frogs during outbreaks, at other sites in North America researchers often found fewer than 1 or 2 moribund or dead animals (Green et al. 2002). To determine whether $B d$ is causing disease outbreaks and local population declines, intensive population monitoring programs must be established in areas that have susceptible species and climatic conditions that are favorable to $B d$.

Because chytridiomycosis and other emerging infectious diseases can invade and decimate amphibian populations even in relatively remote areas (Lips et al. 2006), populations in refuges and parks with high human visitation are clearly vulnerable (Collins \& Storfer 2003). Many of the $B d$-infected populations we documented are in national parks and in close proximity to hotspots of high amphibian endemism, such as the diverse plethodontid salamander assemblages in and around Great Smoky Mountains National Park. Although we did not find infected plethodontids, other researchers have documented $B d$ infection in wildcaught plethodontids (e.g. Bolitoglossa spp. and Oedipina spp., Lips et al. 2006; Plethodon neomexicanus, Cummer et al. 2005; Eurycea cirrigera, Byrne et al. 2008; Eurycea bislineata and Desmognathus fuscus, Grant et al. 2008). Furthermore, at least 1 species of terrestrial salamander (Plethodon metcalfi) has been shown to be susceptible to chytridiomycosis following experimental exposure to $B d$ (V. M. Vazquez et al. unpubl.).

Pond-breeding amphibians, which exhibited high prevalence of infection in our study, could serve as vectors by spreading $B d$ to other wetlands or to plethodontid salamander populations. Aquatic-breeding salamanders migrate through terrestrial habitats in spring and summer when the ground is wet and efts of Notophthalmus viridescens emerge from their natal ponds and spend up to 7-8 yr in the forest before returning to an aquatic life as adults. Because $B d$ is susceptible to desiccation, it is unlikely to persist in terrestrial environments far from water. In addition, terrestrially-breeding salamanders do not aggregate in large numbers, reducing the probability of $B d$ transmission and mass die-offs (Kriger \& Hero 2007). Of greater concern is the possibility that infected pond breeders could spread $B d$ to stream salamander assemblages during migration or while overwintering. The simple metapopulation model developed by McCallum \& Dobson (2002) showed that a highly susceptible host may persist in association with a reservoir species, provided the susceptible host has a high colonization rate. However, with their limited dispersal ability and relatively low fecundity, species of plethodontid salamanders that are highly susceptible would probably have little chance of persisting in the presence of reservoir species. Thus, we suggest that a high priority for research should be determining $B d$ prevalence and susceptibility in salamander populations in the Appalachian Highlands.

In general, studies examining prevalence within populations and communities over time and the level of infection of individuals (using histopathological analysis or real-time PCR) would be more informative than merely determining the presence or absence of infection (Daszak et al. 2005, Rachowicz et al. 2006). That is, we see little added benefit of expanding presence-absence surveys for $B d$ occurrence in the southeastern USA in the species studied so far and believe it is time to shift our attention to the question of population- and community-level effects. Even in the absence of strong evidence for population declines, experimental studies are warranted to investigate the potential sublethal effects and fitness consequences of $B d$ infection (e.g., Parris \& Cornelius 2004). In particular, studies of potential interactions between $B d$ infection and stressors, such as contaminants, other diseases, and predators, are urgently needed (e.g., Davidson et al. 2007).

Finally, chytridiomycosis is only one of several emerging infectious diseases that may threaten amphibian populations in our region. We stress the need for ongoing disease surveillance and correct handling of sick and dead amphibians for analysis. There is also a great need for increased funding for analysis of specimens, for more pathologists who can perform the diagnostic work, and for a centralized reporting system for their findings on amphibian diseases. Regardless of $B d$ occurrence, field researchers should continue to follow disinfection protocols to avoid introducing unfamiliar strains and other pathogens to new areas (Berger et al. 2005).

Acknowledgements. B.B.R. thanks the following for field collections: K. Fristrup, J. Gibbs, S. Rothermel; the following for permission to collect: Georgia Wildlife Federation, South Carolina Department of Natural Resources, Georgia Department of Natural Resources; the following for information: K. Grayson, J. Byrd; the following for figure preparation: D. Catellier, W. J. Barichivich; and the following for funding: National Park Service, US Department of Interior, Savannah River Ecology Laboratory (under Financial Assistance Award DE-FC09-96SR18-546 between the University of Georgia and the US Department of Energy), Declining Amphibian Populations Task Force. S.C.W. thanks the following for field collection: D. Drake, J. Doherty, K. Wharton; the following for permission to collect: Atchafalaya NWR, Sherburne WMA, Louisiana Department of Wildlife and Fisheries; the following for information: L. LaClaire, M. Sisson; and the following for funding: Amphibian Research and Monitoring Initiative (ARMI), US Geological Survey. J.C.M. thanks the following for field collection: C. Ten Brink, K. Dyer, R. Gaul, T. Georgel, J. Hall, C. Wigent, B. Willis-Stevenson; and the following for funding: US DoD Legacy Resource Management Program to 
J.C.M., National Science Foundation grant to M. Garcia of Virginia Commonwealth University. C.K.D. thanks the following for field collection: J. Corser, S. Johnson, W. J. Barichivich, J. Staiger, D. Gregoire; the following for permission to collect: Great Smoky Mountains National Park, Ordway-Swisher Biological Station, Withlacoochee State Forest, US Fish and Wildlife Service; and the following for funding: ARMI, US Geological Survey. L.K.I. thanks the following for field collection: R. Woods, D. Linden, C. Parker, G. Gooding, K. Nguyen, T. Crabill, M. Brady, J. Warren. All research was conducted in compliance with the relevant institutional animal care and use guidelines. Use of trade or product names does not imply endorsement by the US Government.

\section{LITERATURE CITED}

Annis SL, Dastoor FP, Ziel H, Daszak P, Longcore JE (2004) A DNA-based assay identifies Batrachochytrium dendrobatidis in amphibians. J Wildl Dis 40:420-428

Berger L, Speare R, Daszak P, Green DE and others (1998) Chytridiomycosis causes amphibian mortality associated with population declines in the rainforests of Australia and Central America. Proc Natl Acad Sci USA 95:9031-9036

- Berger L, Marantelli G, Skerratt LF, Speare R (2005) Virulence of the amphibian chytrid fungus Batrachochytrium dendrobatidis varies with the strain. Dis Aquat Org 68:47-50

Bosch J, Carrascal LM, Duran L, Walker S, Fisher MC (2007) Climate change and outbreaks of amphibian chytridiomycosis in a montane area of Central Spain; is there a link? Proc R Soc Lond B Biol Sci 274:253-260

Boyle DG, Boyle DB, Olsen V, Morgan JAT, Hyatt AD (2004) Rapid quantitative detection of chytridiomycosis (Batrachochytrium dendrobatidis) in amphibian samples using real-time Taqman PCR assay. Dis Aquat Org 60: 141-148

Briggs CJ, Vredenburg VT, Knapp RA, Rachowicz LJ (2005) Investigating the population-level effects of chytridiomycosis: an emerging infectious disease of amphibians. Ecology 86:3149-3159

Byrne MW, Davie EP, Gibbons JW (2008) Batrachochytrium dendrobatidis occurrence in Eurycea cirrigera. Southeast Nat 7:551-555

Carey C, Bradford DF, Brunner JL, Collins JP and others (2003) Biotic factors in amphibian population declines. In: Linder G, Krest SK, Sparling DW (eds) Amphibian decline: an integrated analysis of multiple stressor effects. SETAC Press, Pensacola, FL, p 153-208

Carey C, Bruzgul JE, Livo LJ, Walling ML and others (2006) Experimental exposures of boreal toads (Bufo boreas) to a pathogenic chytrid fungus (Batrachochytrium dendrobatidis). EcoHealth 3:5-21

Collins JP, Storfer A (2003) Global amphibian declines: sorting the hypotheses. Divers Distrib 9:89-98

Cummer M, Green DE, O'Neill EM (2005) Aquatic chytrid pathogen detected in terrestrial plethodontid salamander. Herpetol Rev 36:248-249

> Daszak P, Cunningham AA, Hyatt AD (2003) Infectious disease and amphibian population declines. Divers Distrib 9:141-150

Daszak P, Streiby A, Cunningham AA, Longcore JE, Brown CC, Porter D (2004) Experimental evidence that the bullfrog (Rana catesbeiana) is a potential carrier of chytridiomycosis, an emerging fungal disease of amphibians. Herpetol J 14:201-207

> Daszak P, Scott DE, Kilpatrick AM, Faggioni C, Gibbons JW,
Porter D (2005) Amphibian population declines at Savannah River Site are linked to climate, not chytridiomycosis. Ecology 86:3232-3237

Davidson C, Benard MF, Shaffer HB, Parker JM, O'Leary C, Conlon JM, Rollins-Smith LA (2007) Effects of chytrid and carbaryl exposure on survival, growth and skin peptide defenses in foothill yellow-legged frogs. Environ Sci Technol 41:1771-1776

- Davis AK, Yabsley MJ, Keel MK, Maerz JC (2007) Discovery of a novel alveolate pathogen affecting southern leopard frogs in Georgia: description of the disease and host effects. EcoHealth 4:310-317

DiGiacomo RF, Koepsell TD (1986) Sampling for detection of infection or disease in animal populations. J Am Vet Med Assoc 189:22-23

Dodd CK Jr (2004) The amphibians of Great Smoky Mountains National Park. University of Tennessee Press, Knoxville, TN

Dodd CK Jr, Barichivich WJ (2007) Establishing a baseline and faunal history in amphibian monitoring programs: the amphibians of Harris Neck, Georgia, USA. Southeast Nat 6:125-134

Dodd CK Jr, Barichivich WJ, Johnson SA, Staiger JS (2007) Changes in a Florida panhandle Gulf Coast herpetofaunal community over a 28-year period. Am Midl Nat 158:29-48

Eisenberg JF, Franz RF (1995) Foreword. In: Eisenberg JF, Franz RF (eds) Natural history of the Katharine Ordway Preserve-Swisher Memorial Sanctuary, Putnam County, Florida. Bull Florida Mus Nat Hist 38:i-v

Grant EHC, Bailey LL, Ware JL, Duncan KL (2008) Prevalence of the amphibian pathogen Batrachochytrium dendrobatidis in stream and wetland amphibians in Maryland, USA. Appl Herpetol 5:233-241

Green DE, Converse KA (2005) Diseases of frogs and toads. In: Mujumdar SK, Brenner JE, Panah AI (eds) Wildlife diseases: landscape epidemiology, spatial distribution and utilization of remote sensing technology. Pennsylvania Academy of Science, Easton, PA, p 89-117

Green DE, Dodd CK Jr (2007) Presence of amphibian chytrid fungus Batrachochytrium dendrobatidis and other amphibian pathogens at warmwater fish hatcheries in southeastern North America. Herpetol Conserv Biol 2: 43-47

Green DE, Converse KA, Schrader AK (2002) Epizootiology of sixty-four amphibian morbidity and mortality events in the USA, 1996-2001. Ann N Y Acad Sci 969:323-339

Hopkins S, Channing A (2003) Chytrid fungus in northern and western Cape frog populations, South Africa. Herpetol Rev 34:334-336

King SL, Keeland BD (1999) Evaluation of reforestation in the lower Mississippi River Alluvial Valley. Restor Ecol 7: 348-359

Kriger KM, Hero JM (2006) Large-scale seasonal variation in the prevalence and severity of chytridiomycosis. J Zool 271:352-359

Kriger KM, Hero JM (2007) The chytrid fungus Batrachochytrium dendrobatidis is non-randomly distributed across amphibian breeding habitats. Divers Distrib 13: 781-788

Lips KR, Brem F, Brenes R, Reeve JD and others (2006) Emerging infectious disease and the loss of biodiversity in a neotropical amphibian community. Proc Natl Acad Sci USA 103:3165-3170

Lips KR, Diffendorfer J, Mendelson JR III, Sears MW (2008) Riding the wave: reconciling the roles of disease and climate change in amphibian declines. PLoS Biol 6:e72

Livo LJ (2004) Methods for obtaining Batrachochytrium den- 
drobatidis $(B d)$ samples for PCR testing. Colorado Division of Wildlife, Denver, CO. Available at: http://wildlife.state. co.us/NR/rdonlyres/710BBC95-2DCF-4CF9-8443-D4561D BC3B69/0/PCRsampling2004.pdf

Longcore JE, Pessier AP, Nichols DK (1999) Batrachochytrium dendrobatidis gen, et sp. nov., a chytrid pathogenic to amphibians. Mycologia 91:219-227

Longcore JR, Longcore JE, Pessier AP, Halteman WA (2007) Chytridiomycosis widespread in anurans of northeastern United States. J Wildl Manage 71:435-444

McCallum H (2005) Inconclusiveness of chytridiomycosis as the agent in widespread frog declines. Conserv Biol 19: 1421-1430

McCallum H, Dobson A (2002) Disease, habitat fragmentation and conservation. Proc R Soc Lond B Biol Sci 269: 2041-2049

McLauglin GS, Green DE, Sohn R, Converse K (2006) Collection, preservation and mailing of amphibians for diagnostic examinations. National Wildlife Health Center, Madison, WI. Available at: www.nwhc.usgs.gov/publications/ amphibian_research_procedures/specimen_collection.jsp

Morehouse EA, James TY, Ganley ARD, Vilgalys R, Berger L, Murphy PJ, Longcore JE (2003) Multilocus sequence typing suggests the chytrid pathogen of amphibians is a recently emerged clone. Mol Ecol 12:395-403

Morgan JAT, Vredenburg VT, Rachowicz LJ, Knapp RA and others (2007) Population genetics of the frog-killing fungus Batrachochytrium dendrobatidis. Proc Natl Acad Sci USA 104:13845-13850

Muths E, Corn PS, Pessier AP, Green DE (2003) Evidence for disease-related amphibian decline in Colorado. Biol Conserv 110:357-365

NWHC (National Wildlife Health Center) (2005) Quarterly wildlife mortality report January 2005 to March 2005 NWHC, Madison, WI. Available at: www.nwhc.usgs.gov/ publications/quarterly_reports/2005_qtr_1.jsp

Ouellet M, Mikaelian I, Pauli Bd, Rodrigue J, Green DM (2005) Historical evidence of widespread chytrid infection in North American amphibian populations. Conserv Biol 19:1431-1440

Padgett-Flohr GE, Bommarito T, Sparling D (2007) Amphibian chytridiomycosis in commercially purchased research amphibians. Herpetol Rev 38:390-393

Parris MJ, Cornelius TO (2004) Fungal pathogen causes competitive and developmental stress in larval amphibian communities. Ecology 85:3385-3395
Pearl CA, Bull EL, Green DE, Bowerman J, Adams MJ, Hyatt A, Wente WH (2007) Occurrence of the amphibian pathogen Batrachochytrium dendrobatidis in the Pacific Northwest. J Herpetol 41:145-149

Peterson JD, Wood MB, Hopkins WA, Unrine JM, Mendonça MT (2007) Prevalence of Batrachochytrium dendrobatidis in American bullfrog and southern leopard frog larvae from wetlands on the Savannah River Site, South Carolina. J Wildl Dis 43:450-460

> Petranka JW, Kennedy CA, Murray SM (2003) Response of amphibians to restoration of a southern Appalachian wetland: a long-term analysis of community dynamics. Wetlands 23:1030-1042

Petranka JW, Harp EM, Holbrook CT, Hamel JA (2007) Longterm persistence of amphibian populations in a restored wetland complex. Biol Conserv 138:371-380

Pounds JA, Bustamante MR, Coloma LA, Consuegra JA and others (2006) Widespread amphibian extinctions from epidemic disease driven by global warming. Nature 439:161-167

Rachowicz LJ, Knapp RA, Morgan JAT, Stice MJ, Vredenburg VT, Parker JM, Briggs CJ (2006) Emerging infectious disease as a proximate cause of amphibian mass mortality. Ecology 87:1671-1683

Retallick RWR, Miera V (2007) Strain differences in the amphibian chytrid Batrachochytrium dendrobatidis and non-permanent, sub-lethal effects of infection. Dis Aquat Org 75:201-207

Retallick RWR, McCallum H, Speare R (2004) Endemic infection of the amphibian chytrid fungus in a frog community post-decline. PLoS Biol 2:e351

Ron SR (2005) Predicting the distribution of the amphibian pathogen Batrachochytrium dendrobatidis in the New World. Biotropica 37:209-221

Tuberville TD, Willson JD, Dorcas ME, Gibbons JW (2005) Herpetofaunal species richness of southeastern national parks. Southeast Nat 4:537-569

Voyles J, Berger L, Young S, Speare R and others (2007) Electrolyte depletion and osmotic imbalance in amphibians with chytridiomycosis. Dis Aquat Org 77:113-118

Weldon C, du Preez LH, Hyatt AD, Muller R, Speare R (2004) Origin of the amphibian chytrid fungus. Emerg Infect Dis 10:2100-2105

Zar JH (1999) Biostatistical analysis, 4th edn. Prentice Hall, Upper Saddle River, NJ 
Appendix 1. Descriptions of study sites surveyed for the presence of Batrachochytrium dendrobatidis in amphibians

Bald Knob National Wildlife Refuge (NWR), White County, Arkansas. This 5989 ha refuge is located approximately $97 \mathrm{~km}$ northeast of the center of the state in the Mississippi Alluvial Valley. Approximately 2428 ha of the refuge is cropland, primarily cultivated in rice. Another 1821 ha consists of bottomland hardwood forests and associated sloughs and oxbows, and the remaining 1578 ha consists of reforested agricultural fields. Bald Knob NWR is surrounded by the extensive agricultural lands of the Mississippi River delta.

Felsenthal NWR, Ashley, Union, and Bradley Counties, Arkansas. This refuge in southern Arkansas encompasses the confluence of the Ouachita and Saline Rivers and falls within the West Gulf Coastal Plain physiographic region. It consists of 16188 ha of bottomland hardwood forest, 6070 ha of open water, and 4047 ha of upland mixed pine-hardwood forest. Extensive oil production areas lie immediately north and west of the refuge boundaries, with limited historical and current oil production within the northern refuge boundary. Felsenthal NWR lies in a watershed where elevated mercury, chlorides, and petroleum constituents are contaminants of concern.

Ordway-Swisher Biological Station, Putnam County, Florida. The Ordway-Swisher Biological Station consists of ca. 4364 ha of mixed uplands and wetlands managed by the University of Florida. The preserve lies on the southern edge of Trail Ridge within the Interlachen Karstic Highland. Nine major communities have been identified on the preserve. Uplands consist mostly of sandhills, xeric hammocks, and a mixed upland forest undergoing succession from open fields to forest. Wetlands consist of the Mill Creek system (a series of inter-connected red water eutrophic lakes and swamp forest) and isolated clear water oligotrophic lakes and depression marshes. These communities are interspersed in a complex mosaic pattern throughout the preserve, and the sandhills community, in particular, is managed using prescribed fire on a rotational schedule (Eisenberg \& Franz 1995).

St. Marks NWR, Wakulla County, Florida. Located in Florida's panhandle approximately $25 \mathrm{~km}$ south of Tallahassee, St. Marks NWR encompasses 27500 ha of diverse upland and wetland habitats. Established in 1931 to provide wintering habitat for migratory birds, St. Marks NWR extends along the Gulf coast in Taylor, Jefferson, and Wakulla Counties. For management purposes, the refuge is divided into 3 major units. Wetlands at St. Marks NWR potentially support 40 species of amphibians, including the flatwoods salamander Ambystoma cingulatum, a federally threatened species. Wetlands include hundreds of temporary freshwater depression marshes which fill and dry according to local seasonal rainfall patterns. Other wetlands include lakes, seeps, streams and rivers, swamps, roadside ditches, and springs. During low water, these wetlands may be isolated, but during periods of high water and during tropical storms, sheet flow may interconnect many of them. St. Marks also may be affected by saltwater storm tides during tropical storms. St. Marks NWR is used by outdoor recreationists, and is managed using prescribed fire for biodiversity and timber production (Dodd et al. 2007).

Withlacoochee State Forest, Hernando County, Florida. Withlacoochee State Forest is located in west central Florida immediately north of the town of Brooksville, and $83 \mathrm{~km}$ northeast of Tampa. Withlacoochee State Forest was acquired by the federal government from private landowners between 1936 and 1939; it is the third largest state forest in Florida. The Florida Division of Forestry manages the land for multiple-use of the forest resources, including timber, wildlife, ecological restoration, and outdoor recreation. The forest is divided into 8 distinct tracts of land; amphibian diseases thus far have been documented on the Croom Tract. This area consists of sandhill uplands along the Brooksville Ridge, a longleaf pine/turkey oak/ wiregrass community interspersed by temporary, oligotrophic, clear-water ponds and depression marshes.

Wekiwa Springs State Park, Orange County, Florida. This approximately 3200 ha state park, opened in 1970, is located near the town of Apopka north of Orlando. The area consists of extensive tracts of sub-tropical mesic forest adjacent to the large Wekiva Springs, Rock Springs, and many smaller springs in the vicinity, which merge to form the Wekiva River. Adjacent uplands consist largely of a sandhills community of longleaf pine Pinus palustris, turkey oak Quercus laevis and wiregrass Aristida beyrichiana which is fire-managed.

Chattahoochee River National Recreation Area (NRA), Cobb County, Georgia. Because of its location in the Atlanta metropolitan area, this US Department of Interior site is embedded in an urbanizing landscape and is visited by more than 2.5 million people per year. We sampled in a park unit along the Chattahoochee River corridor on the north side of Atlanta, which is in the Piedmont physiographic region. Twenty-three species of amphibians occur in the park, including 4 species of Rana (Tuberville et al. 2005).

Fort Stewart, Bryan, Evans, Liberty, Long, and Tattnall Counties, Georgia. Fort Stewart (113000 ha) is home of the 3rd Infantry Division (Mechanized, US Army) and is located ca. $20 \mathrm{~km}$ west of Savannah. Fort Stewart is entirely within the Lower Coastal Plain physiographic province. Significant stands of Pinus palustris/Aristida stricta flatwoods and sandhills occur on the installation; these sites support noteworthy populations of protected or rare amphibian species including Ambystoma cingulatum, striped newt Notophthalmus perstriatus, and gopher frog Rana capito. An aggressive prescribed burn program is in place to manage and enhance these fire-dependent ecosystems. Freshwater wetlands are extensive (total ca. 37000 ha), and include isolated depressional wetlands, blackwater creek swamps, seepage-influenced bay swamps, floodplain pools, and anthropogenic sites (e.g. borrow pits, ditches). Twenty-one species of anurans and 17 species of salamanders have been documented for this military installation (D. J. Stevenson unpubl. 1999 report to the Fort Stewart Fish and Wildlife Branch, Georgia).

Harris Neck NWR, McIntosh County, Georgia. Harris Neck NWR is located ca. $46 \mathrm{~km}$ south of Savannah and $31 \mathrm{~km}$ north of Darien. The refuge comprises 1255 ha of mostly coastal deciduous and oak woodlands, grasslands, former cropland, and some pine, and is surrounded by salt marshes and tidal creeks, limiting amphibian colonization. Harris Neck has a long history of human occupation (Amerindian, plantations prior to the Civil War, a series of many small farms in the late 1800s-early 1900s, an airfield, a military base during World War II); since World War II it has been under the ownership and management of several government agencies. Harris Neck became a National Wildlife Refuge in 1962, and is managed primarily for waterfowl and wading birds, especially the wood stork. Nearly all the wetlands at Harris Neck are man-made impoundments, modified former tidal creeks, or ditches and borrow pits; 13 amphibians are known from the refuge (Dodd \& Barichivich 2007). 
Appendix 1 (continued)

Upper Tallulah River Site, Towns County, Georgia. This 53 ha tract in the Blue Ridge physiographic province is owned and managed by the Georgia Wildlife Federation for research and education purposes. The property adjoins the Southern Nantahala Wilderness Area and encompasses the confluences of Beech Creek and Burnt Cabin Branch with the Tallulah River. The ravines and north-facing bluffs of these creeks are dominated by northern hardwoods and hemlock, a vegetation community that normally occurs above $1200 \mathrm{~m}$ but is found here below $900 \mathrm{~m}$. A large meadow in the river valley contains several manmade ponds, including 2 permanent ponds and a linear series of pools fed by water diverted from the Tallulah River. At least 12 species of salamanders and 5 species of anurans occur at this site (M. E. McGhee, Georgia Museum of Natural History, pers. comm.; B. B. Rothermel pers. obs.).

Big Branch Marsh NWR, St. Tammany Parish, Louisiana. This refuge is located along the north shore of Lake Pontchartrain in the East Gulf Coastal Plain. It consists of 6070 ha of fresh and brackish marshes, pine islands, pine ridges, cypress swamps, and hardwood hammocks. Numerous bayous, estuaries, and ponds dominate this diverse refuge.

D'Arbonne NWR, Ouachita and Union Parishes, Louisiana. Located in north-central Louisiana in the Mississippi Alluvial Valley, the D'Arbonne NWR consists of 7049 ha of bottomland hardwood forest, upland forest, moist soil habitats and permanent open water areas, primarily Bayou D'Arbonne.

Lake Ophelia NWR, Atchafalaya NWR, and Sherburne Wildlife Management Area (WMA), Louisiana. Lake Ophelia and Atchafalaya National Wildlife Refuges and the Sherburne Wildlife Management Area are contained within the Lower Mississippi Alluvial Valley (LMAV) of Louisiana. The Atchafalaya Basin is the nation's largest swamp wilderness (240 793 ha), containing nationally significant expanses of bottomland hardwoods, swamplands, bayous and back-water lakes. The bottomland hardwood forest ecosystem that characterizes the LMAV has been highly fragmented and subjected to extensive hydrologic alterations during the last century (King \& Keeland 1999). Within the Basin, the Sherburne WMA (4767.3 ha), Atchafalaya NWR (6159.4 ha) and US Army Corps of Engineers lands (6725.2 ha) combine to form a 17652 ha tract within Saint Martin, Pointe Coupee and Iberville Parishes along the Atchafalaya River, a tributary of the Mississippi. The area is managed as 1 unit by the Louisiana Department of Wildlife and Fisheries. Lake Ophelia NWR is a 7050 ha refuge located in Avoyelles Parish, Louisiana along the Red River which, like the Atchafalaya, is a tributary of the Mississippi.

Dahomey NWR, Bolivar County, Mississippi. Located in the Mississipi Alluvial Valley, this 3922 ha refuge is the largest remaining tract of bottomland hardwood forest in the northwestern portion of the state, and has limited cooperative farming, primarily rice.

Desoto National Forest (NF), Harrison County, Mississippi. Pony Ranch Pond, Reserve Pond, Glen's Pond, and the Rifle Range borrow pit are located on the Desoto NF in Harrison County, Mississippi. Glen's, Pony Ranch and Reserve are natural depressional wetlands with open canopies that are situated in longleaf pine habitat. These sites are ephemeral and are exposed to prescribed fire as a habitat management practice. These sites have a history of tree removal, although they would also have had fairly open canopies prior to tree removal. At least 18 anuran species and 3 salamander species occur in the area of Glen's Pond (M. Sisson pers. comm.).

Yazoo NWR, Washington County, Mississippi. Yazoo NWR is located in the Mississippi Alluvial Valley, approximately $6.4 \mathrm{~km}$ east of the Mississippi River. It consists of 5269.5 ha of oxbow lakes, mature cypress/ash woodlands, green-tree reservoirs, moist soil units, cultivated fields and reforested areas. Elevated fish tissue levels of DDT and other persistent organochlorines prevent public fishing access on Yazoo NWR. Aerial drift of current use pesticides onto the refuge is also likely given its location within the extensive agricultural basin of the Mississippi Delta.

Camp Lejeune, Oslow County, North Carolina. This is a large US Marine Corps training base covering about 72000 ha in the lower Coastal Plain. Training exercises in the target area consist mostly of foot traffic, although few marines enter the wetlands during their activities. The area sampled by J. C. Mitchell consisted of 30 'limesinks,' natural isolated wetlands varying in size from 0.1 ha to 6 ha. All are shallow with abundant emergent vegetation and grasses along the edges of most ponds. These ponds support a wide diversity of invertebrates and amphibians. Nineteen species of anurans and 5 species of salamanders have been documented for this area (J. C. Mitchell unpubl. 2002 report to the Legacy Resource Management Program, US Dept. of Defense, Arlington, Virginia). The mixed hardwood and pine forest surrounding the wetlands was damaged by hurricanes in the mid- and late 1990s and has been under intensive forest management.

Nantahala NF, Macon and Jackson Counties, North Carolina. Salamanders for this study were collected from forest floor, stream, and rock face habitats within a $6 \mathrm{~km}$ radius of the Highlands Biological Station. Although most of the salamanders were collected from sites on US Forest Service property, a few were also collected from within the botanical garden of the Biological Station. This site is located on the Highlands Plateau of the Blue Ridge physiographic province at an elevation of approximately $1200 \mathrm{~m}$. The climate is characterized by cool, mild temperatures (daily maxima rarely exceeding $27^{\circ} \mathrm{C}$ ) and average annual precipitation of $2000-2500 \mathrm{~mm}$, qualifying it as temperate rainforest. Typical plant communities include mesophytic cove forests and hemlock-dominated forests with a dense understory of Rhododendron sp. along streams. With its cool, moist environmental conditions and topographic variety, the Southern Appalachians region supports the world's highest diversity of salamanders, particularly of species in the Family Plethodontidae.

Tulula Wetlands Mitigation Site, Graham County, North Carolina. This is a disturbed 95 ha wetland restoration site located $4.8 \mathrm{~km}$ west of Topton in the Blue Ridge physiographic province (elevation range $784-800 \mathrm{msl}$ ). The site is an isolated wetlands complex that is surrounded by steep mountains and has no known connectivity to adjoining wetlands. The site originally contained scattered depressional fens, but was degraded in the mid to late 1980s by a failed attempt to build a golf course on site. Site restoration included the construction of breeding ponds for amphibians, and the site currently contains about 39 primary breeding sites (Petranka et al. 2003). Seventeen species of amphibians occur on site, including pondbreeding, stream-breeding, and terrestrial-breeding species.

Congaree National Park (NP), Richland County, South Carolina. This 8984 ha park in the Upper Coastal Plain includes the largest intact tract of old-growth floodplain forest in the USA. The park receives approximately 100000 recreational visits per 
Appendix 1 (continued)

year and allows low-impact activities such as hiking, canoeing and kayaking, and fishing. Natural disturbances such as seasonal flooding and hurricanes have a large influence on the vegetation and ecology of the swamp (e.g. Hurricane Hugo in 1989). Twenty-nine species of amphibians occur in the park, including 6 species of Rana (Tuberville et al. 2005).

Great Smoky Mountains NP, Blount County, Tennessee. Most of the temporary ponds and wetlands in this $>2100 \mathrm{~km}^{2}$ national park are located in Cades Cove and nearby Big Spring Cove. These valleys are underlain by Ordovician limestones wherein sinkholes form, providing normally reliable amphibian breeding sites. Cades Cove consists of approximately 3090 ha, of which 1091 ha are open fields. The valley is drained by Abrams Creek and its tributaries, which empty northwestward into the Little Tennessee River. Low depressions in the valley floor, such as Gum Swamp, also allow the accumulation of water during the spring and early summer, but these dry during the summer or when winter and spring rains are deficient. Indeed, some of the wetlands may fill and dry several times within a year. Most of the wetlands in Cades Cove fill depending on ground water levels, although the only site in which amphibian diseases have been identified, Gourley Pond, receives overflow from a nearby stream during high water. Dodd (2004) provides additional information on the wetlands and associated physiography of the park. This park is the most visited national park in the United States, and Cades Cove is one of the most popular destinations.

University of Tennessee Arboretum, Anderson County, Tennessee. The 915 ha Oak Ridge Forest unit of the University of Tennessee Forestry Experimental Station and Arboretum is located in the Valley and Ridge physiographic province. The land has been protected from uncontrolled fires and has had limited timber harvest since 1962, when it was bought by the University of Tennessee from the US Atomic Energy Commission. The area is a highly fragmented mosaic of field and forest habitats, including stands of upland hardwood and mixed hardwood/pine. Amphibian specimens were collected at the Forestry Station garage, which receives regular vehicular traffic and is in close proximity to a powerline right-of-way. The adjacent forest is mixed hardwood consisting primarily of Quercus spp. and Carya spp.

Mountain Lake Biological Station, Giles County, Virginia. Mountain Lake Biological Station is located in the Allegheny Mountains of southwestern Virginia at an elevation of $1160 \mathrm{~m}$. The station is about $2 \mathrm{~km}$ from Mountain Lake, the only natural lake in the unglaciated Appalachians. Sick and dead red-spotted newts Notophthalmus v. viridescens were collected from Sylvatica and Horton ponds, which are small ( $<0.03$ ha and $<1.3 \mathrm{~m}$ deep), man-made ponds located only $50 \mathrm{~m}$ apart. Both ponds are permanent, fishless, and surrounded by mixed deciduous forest (K. Grayson pers. comm.). Several other pondbreeding amphibians are also present at this site, including wood frogs Rana sylvatica, green frogs $R$. clamitans, American bullfrogs $R$. catesbeiana, spring peepers Pseudacris crucifer, and Jefferson salamanders Ambystoma jeffersonianum.

Upham Brook, Henrico County, Virginia. Upham Brook is a second-order stream that drains a highly urbanized and residential watershed in the city of Richmond and adjacent areas on the eastern margin of the Piedmont physiographic province. Upham Brook varies from about $3 \mathrm{~m}$ to $10 \mathrm{~m}$ in width, with a silty bottom in most reaches. Some of the upper portion of this stream is bordered by mixed hardwoods in the floodplain, whereas in lower reaches the stream border consists of lawns and public ball fields and golf courses. Ten species of anurans and 3 species of salamanders have been recorded for this stream (J. C. Mitchell unpubl. obs.). Input into the stream from human sources includes human sewage in the recent past, petrochemical products from roads, parking lots and a train yard at the headwaters, trash, and herbicides from lawns and golf courses in the watershed.

Editorial responsibility: Alex Hyatt, Geelong, Victoria, Australia
Submitted: October 9, 2007; Accepted: August 8, 2008

Proofs received from author(s): October 13, 2008 